\title{
Aszimmetrikus kereskedelmi kapcsolatok az olasz-líbiai viszonylatban
} Asymmetric Trade Relations between Italy and Libya

\begin{abstract}
Absztrakt
Olaszországot és Libiát szoros kapcsolatok füzik egymáshoz a gazdasági biztonság területén, ez azonban nincs a tudományos kutatások középpontjában. Az aszimmetrikus gazdasági kapcsolatok a nagyobb állam számára politikai befolyást is biztosithatnak. Az olasz-líbiai kereskedelmi kapcsolatok nagy részét a líbiai kőolaj és földgáz Olaszországba való exportja teszi ki, aminek a mennyisége 2011 óta jelentősen csökkent. Az ENI a legnagyobb külföldi szereplö Líbiában, így az ottani olasz befolyás egyik letéteményese. Az energiahordozók kereskedelme terén nincs olyan erős aszimmetria a bilaterális kapcsolatokban, mint az egyéb termékek terén, hiszen Libia egy úgynevezett rentier state, ${ }^{2}$ igy az Olaszországba irányuló szállitásra szüksége van. A kereskedelmi kapcsolatok egyéb területein erös aszimmetria van Olaszország irányába, bár az arab tavasz óta líbiai piaci részesedése csökkent.
\end{abstract}

Kulcsszavak: Olaszország, Líbia, energiahordozók, gazdasági kapcsolatok, aszimmetria

\begin{abstract}
Italy and Libya have strong ties in the field of economic security; however, this has not been in the centre of academic attention. Asymmetric economic relations can result in political influence for the larger states. Italo-Libyan trade relations are dominated by the export of Libyan oil and natural gas to Italy. The quantity of the energy export has reduced since 2011. ENI is the biggest foreign actor in Libya; thus, it is of utmost importance for Rome to guarantee Italian influence in Libya. Asymmetry in energy trade

Nemzeti Közszolgálati Egyetem Hadtudományi Doktori Iskola, doktori hallgató - University of Public Service Doctoral School of Military Sciences, PhD student, e-mail: takacs.lili@uni-nke.hu

2 Rentier state alatt olyan államot értünk, amely az energiahordozók exportjából származó bevételből finanszírozza működését.
\end{abstract}


is not as significant as in other trade areas, since Libya is a rentier state and as such it depends on oil revenues. In other trade areas, there is a significant asymmetry with Italian domination, even though its market share has decreased since the Arab Spring.

Keywords: Italy, Libya, energy, trade relations, asymmetry

\section{Bevezetés}

Olaszország kül- és biztonság, valamint külgazdasági politikája három fö, stratégiainak minősíthető irányra fókuszál: atlanti kapcsolatok, európai kapcsolatok és a mediterrán térséggel való kapcsolatok. A mediterrán térségen belül Líbia az az ország, amellyel Róma a gyarmati időszak óta kiemelt kapcsolatokat ápol. Olaszország líbiai érdekeit három fő csoportra különíthetjük el, amelyek a Buzan-féle szektoriális biztonság elméletének különböző szektorait ${ }^{3}$ fedik le: 1 . a stabil gazdasági kapcsolatok megőrzése és a két ország közti kereskedelmi forgalom bővítése (gazdasági szektor); 2. a Líbiából szállított kőolajon és földgázon keresztül az olaszországi energiabiztonság garantálása és az energiaellátás diverzifikációja (gazdasági szektor); 3. a Földközi-tengeren keresztül Olaszországba irányuló, egyre nagyobb társadalmi feszültségeket keltő illegális migráció megállítása, ezzel a nemzetközi terrorcsoportok Itáliába jutásának megelőzése (társadalmi és katonai szektor). Gyakorlatilag az összes fontosabb külpolitikai, védelmi stratégiai dokumentum, valamint a nemzetbiztonsági szolgálatok éves jelentései külön kiemelik Líbiát mint a térség olasz szempontból legfontosabb államát, amely stratégiai prioritás az olasz kormányok számára. ${ }^{4}$

A három érdek biztosítása kölcsönös függőséget okoz a két ország között, ennek ellenére a kapcsolatukat egyfajta stabil kiegyensúlyozatlanság jellemzi. ${ }^{5}$ Olaszország Líbiára utaltsága azonban az arab tavasz óta azon a területen növekedett leginkább

Barry Buzan: People, States, and Fear: The National Security Problem in International Relations. Brighton, Wheatsheaf Books, 1983.

4 A Jelentés 2020 címü, 2008-ban készült külpolitikai stratégiában Líbia elsősorban az energiabiztonság és a migrációs hullámok miatt jelenik meg, ahol az erős bilaterális kapcsolatok kialakítása és fenntartása szükséges egyrészt az olasz érdekek biztosításához, másrészt pedig a mediterrán térség horizontális integrációja előtt álló (líbiai és algériai) akadályok elgördítéséhez. A védelmi miniszter által évente kiadott hároméves tervekben (Documento Programmatico Pluriennale) az euromediterrán térség prioritási területként szerepel. A 2019-2021-re vonatkozó tervben Líbia - Szíria mellett - kulcsfontosságú euromediterrán térség legtörékenyebb országaként jelenik meg, amely „stratégiai prioritás” Itália számára, hiszen a helyi hatóságok gyengesége következtében könnyebben terjednek olyan destabilizáló tényezők, mint például a migrációs hullámok, a vallási alapú terrorizmus, vagy a szervezett bünözői csoportok, amelyek közvetlenül érintik Olaszország biztonságát A Földközi-tenger déli partvidéke az olasz hírszerzés (Agenzia informazione e sicurezza esterna) számára kiemelt hírszerzési irány. A titkosszolgálatok az éves jelentéseikben visszatérő jelleggel Líbiát jelölik meg mint a térség legfontosabb állama Olaszország számára, 2019-ben az információs tájékoztató munka prioritása a líbiai helyzet volt. A műveleti munkában az AISE a Líbiában levő olasz érdekek és érdekeltségek védelmére, a politikai-diplomáciai lépések előkészítésére és támogatására, a terrorizmus terjedésének megakadályozására és a migrációs hullámokhoz kötődő bünözői körök elleni küzdelemre főkuszált. Marta Dassú - Maurizio Massari (szerk.): „Rapporto 2020 - Le scelte di politica estera. Unità di analisi e di programmazione". Ministero degli Affari Esteri, 2008. 72; Ministero della Difesa: Documento Programmatico per la Difesa per il triennio 2019-2021.; Sisitema di informazione per la sicurezza della Repubblica: Relazione annuale. 2019.

5 Nicola Chelotti - Elisabeth Johansson-Nogues: Stable unpredictability? An assessment of the Italian-Libyan relations. In Ludovica Marchi - Richard Whitman - Geoffrey Edwards (szerk.): Italy's foreign policy in the twenty-first century: a contested nature? London, Routledge, 2014. 178-196. 
(illegális migrációs megállítása), amely a lakosság szubjektív biztonságpercepcióját a legérzékenyebben érinti. ${ }^{6} \mathrm{Az}$ arab tavaszt megelőző négy évtizedben Muammer Kadhafi tisztában volt azzal, hogy az energiahordozókra és az illegális migráció megállítására Olaszországnak biztonsági okokból szüksége van, ezzel jelentősen növelni tudta a saját mozgásterét. Míg Kadhafi számára Olaszország gazdasági szempontból vált elsődleges partnerré, az olaszokat az energiabiztonság garantálása mellett a migráció visszaszorítása késztette a Líbiával való megállapodásokra. A kétoldalú kapcsolatokban az aszimmetria különböző mértékben ugyan, de mind a gazdasági, mind a társadalmi biztonság területén megtalálható volt az arab tavasz előtt, és után is.

2011 vége óta azonban nincs olyan hatalmi központ Líbiában, amely a teljes országra ki tudja terjeszteni a hatalmát, a külső szereplők támogatásával egymással rivalizáló szereplők és az erős törzsi identitás miatt nehéz Líbiát weberi értelemben vett, egységes államként kezelni. Az a zsarolási potenciál, amely korábban egy helyen összpontosult, az arab tavasz, majd a második líbiai polgárháború kitörése óta több, kisebb csoport kezébe került át, ezáltal Olaszország egyre több partnerrel kényszerül egyezségeket kötni. Olaszország líbiai érdekei állandóak maradtak, azonban a politikai közbeszéd, a közhangulat és a lakosság szubjektív biztonságpercepciójának változása miatt a társadalmi biztonság témája (illegális migráció kezelése) kezdte el a kétoldalú kapcsolatokat dominálni, és ez egyben a mediterrán térségbeli olasz külpolitika egyik pillérévé vált.?

A hangsúlyeltolódás következtében az olasz migrációs politika kezelése került a Líbiával foglalkozó tanulmányok fókuszpontjába, ${ }^{8}$ míg a gazdasági kérdésekre kevesebb figyelem irányul. A tanulmány célja, hogy megvizsgálja az olasz-líbiai kétoldalú kapcsolatok gazdasági aspektusainak aktualitásait ${ }^{9}$ Olaszország szempontjából. Líbia instabilitása déli irányból jelentős biztonsági kihívást jelent nemcsak Olaszország számára, hanem az Európai Unióra nézve is, amit tovább súlyosbít, hogy a líbiai helyzet kezelése kapcsán nem létezik közös, uniós álláspont. A politikai viták megléte ellenére Líbia gazdasági támogatása és a líbiai gazdaság működőképességének fenntartása kapcsán egységes, támogató álláspont jellemzi az európai országokat, hiszen a líbiai gazdaság - elsősorban az olajipar - nagyszámú afrikai munkavállalót szív fel.

A tanulmány az elmúlt egy évtized időszakát vizsgálja, az arab tavasz előttre csak annyiban tekintek vissza, amennyiben az a változások mértékének érzékeltetéséhez szükséges. A tanulmányban külön szakaszban vizsgálom az energiahordozókat,

6 Demos \& PI: La percezione degli immigrati. 2017. november; Susana Fereira: Human Security and Migration in Europe's Southern Borders. London, Palgrave Macmillan, 2019. 154.

7 Istituto Affari Internazionali: Gli italiani e la politica estera Rapporto di ricerca a cura di DISPOC/LAPS e IAI. 2017. Marcello Di Filippo - Anja Palm: Le sfide della politica migratoria e il nuovo corso di Minniti. In Ettore Greco (szerk.): L'Italia al bivio. Rapporto sulla politica estera italiana. Róma, Edizioni Cultura, 2018. 65-80; Antonio Zotti - Enrico Fassi: Immigration and Foreign Policy. Italy's domestic-international linkage in the management of mass human movement. Italian Political Science, 15. (2020), 1. 96-113.

8 Lásd Tiziana Torresi: An Emerging Regulatory Framework for Migration. The Libya-Italy Agreement and the Right of Exit. Griffith Law Review, 22. (2013), 3. 648-665; Michele Colucci: Foreign immigration to Italy: crisis and the transformation of flow. Journal of Modern Italian Studies, 24. (2019), 3. 427-440; Derek Lutterbeck: Migrants, weapons and oil: Europe and Libya after the sanctions. The Journal of North African Studies, 14. (2019), 2. 169-184; Michela Ceccorulli - Fabrizio Coticchia:'I'll take two.' Migration, terrorism, and the Italian military engagement in Niger and Libya. Journal of Modern Italian Studies, 25. (2020), 2. 174-196.

9 Tekintettel arra, hogy a kézirat benyújtásakor még nem vált elérhetővé minden, 2020-ra vonatkozó kereskedelmi adat, a Covid-járvány hatásait nem vizsgálom. 
amelyek a kereskedelmi kapcsolatok nagy részét teszik ki, és az egyéb termékeket. Tanulmányomban a gazdasági aszimmetria jelenlétét és természetét vizsgálom a két ország között.

\section{Gazdasági kapcsolatok mint a politikai befolyás eszköze}

Az aszimmetrikus (gazdasági) interdependencia elmélete 1945-ben jelent meg, kidolgozója, Albert Hirschman szerint az államok az aszimmetrikus gazdasági kapcsolatokat politikai célok elérésére használják, a partnerország biztonságának kárára. Hirschman az elméletében bemutatta, hogy az aszimmetrikus kereskedelmi kapcsolatok a nagyobb állam számára politikai előnnyel járnak. Ha ugyanis "A" ország kereskedik a nála kisebb „ $B$ ” országgal, elképzelhető, ez „A” ország kereskedelmének csupán néhány százalékát teszi ki, „B” országban viszont az összkereskedelem felét is meghaladhatja. Ez a nagyobb ország számára kényszerítő erőt biztosít „B” ország felett, mert a (kereskedelmi) kapcsolatok megszakadása " $B$ ” ország számára nagyobb problémát okoznának, mint „A" országnak. A kapcsolatok megszakításával való implicit vagy explicit fenyegetés tehát hatalmat biztosít a nagyobb ország számára. A kényszerítő erő mellett Hirschmannál megjelenik a befolyás fogalma is: leegyszerüsítve Hirschman azt álítja, hogy a nemzetközi gazdasági kapcsolatok hatnak a belpolitikára, ami pedig formálja a nemzeti érdekeket. Ez az aszimmetrikus kapcsolatokban a leglátványosabb, hiszen a hatásai általában széles körűek, látványosak, és átszövik a kisebb ország gazdaságát. ${ }^{10} \mathrm{~A}$ gyakorlatban Hirschman elméletéből inkább a befolyás, mint a kényszerítés figyelhető meg. A nemzetközi politikai magatartás gyakran nem a nyomásgyakorlás miatt változik meg, hanem mert új ösztönzők megváltoztatják a (nemzeti) érdekről alkotott képet.11 A befolyás fogalma kapcsán Hirschmann azt állítja, hogy a függő államra politikailag is befolyást gyakorol a nagyobb állam, ez azonban nem külső fenyegetés hatására történik, hanem a befolyás miatt megváltozik az érdekek percepciója, így a függő állam önként enged a nagyobb állam akaratának, és erre már a saját érdekeként tekint, a kereskedelemből származó gazdasági előnyök miatt. ${ }^{12}$

Az aszimmetrikus interdependencia mint a hatalom forrása a nemzetközi politikai gazdaságtan elterjedt elméletévé vált. ${ }^{13} \mathrm{~A}$ függőség ebben a kontextusban 'szükséget' jelent, az aszimmetria pedig azt jelzi, hogy az egyik félnek nagyobb szükség van a kapcsolatból szerzett előnyökre, mint a másiknak. A kereskedelem és a tőkeáramlás a nemzetközi kapcsolatok fontos formálói, hiszen hozzájárulnak a tág értelemben vett gazdasági fejlődéshez forrástranszferen, munkahelyteremtésen és tudástranszferen keresztül. Az országok közti kereskedelmi kapcsolatokat befolyásolja a köztük fennálló

10 Jó példa erre egy kisebb és egy nagyobb ország között kötött szabadkereskedelmi megállapodás, ami valószínűsíthetően megváltoztatja azt, hogy a kisebb ország miként érzékeli a saját érdekeit: a nagyobb ország érdekeivel fognak konvergálni. Ennek az az oka, hogy a megállapodásban való részvétel önmagában előnyhöz juttatja az abban részt vevőket azokhoz képest, akik nem vesznek benne részt. Ez az előny politikai hatalommá alakulhat.

11 Ez nagyjából megegyezik a Joseph Nye által 'soft power'-ként definiált jelenséggel. Lásd Joseph S. Nye: Bound to Lead: The Changing Nature of American Power. New York, Basic Books, 1990. 188.

12 Albert O Hirschman: National Power and the Structure of Foreign Trade. Berkeley, University of California Press, 1945

13 Lásd például Robert 0. Keohane - Joseph S. Nye: Power and Interdependence: World Politics in Transition. Boston, Little, Brown, 1977. 
politikai kapcsolat minősége is..$^{14}$ Korábban, a hidegháború alatt a kereskedelmi kapcsolatok egyértelműbben tükrözték a politikai kapcsolatok minőségét - ez Olaszország és Líbia esetén a leginkább Líbia 1990-2003 közötti nemzetközi elszigeteltsége alatt mutatkozott meg -, napjainkban azonban a kormányoknak kevesebb mozgástere van a kereskedelem jutalmazásként és/vagy büntetésként való használatára. Részben a WTO szabályozásai, részben pedig a globalizált világkereskedelem ösztönzői megnehezítik a kereskedelmi partnerek diszkriminációját, a transznacionális termelési láncok létrejötte óta pedig nehezebb a külkereskedelmet a külpolitikához igazítani. ${ }^{15}$ A gazdaságpolitika külpolitikai célok elérésére való használata negatív externáliákat hozhat létre az ország belföldi piacán, mert a cégek arra kényszerülnek, hogy kilépjenek a piaci egyensúly helyzetéböl. A külpolitikai eredmények ellenére a geopolitikai érdekek által diktált gazdasági döntések nem feltétlenül hozzák magukkal a legjobb gazdasági eredményt. ${ }^{16}$ Mindezek ellenére a mai napig előfordul, hogy a kormányok politikai viták alapján irányítják a kereskedelmüket.17

\section{Gazdasági kapcsolatok az olasz-líbiai kapcsolatokban}

Olaszország 2019-ben a GDP alapján a világ nyolcadik gazdasága volt, gazdasága erösen exportorientált; ugyanebben az évben a világ kilencedik legnagyobb exportöre és tizenegyedik importőre volt, a kereskedelem tette ki a GDP körülbelülkörülbelül 60\%-át. Majdnem 200000 exportáló vállalkozásának 45\%-a a feldolgozóiparban tevékenykedett, ez adja az exporttevékenység alapját. ${ }^{18}$ Legnagyobb kereskedelmi partnerei az uniós tagállamok mellett az Egyesült Államok és Kína. ${ }^{9}$ Az olasz vállalatok számára a MENA-régió államai földrajzi közelségük miatt stratégiai piacot jelentenek. ${ }^{20}$ Olaszország MENA-térséggel bonyolított kereskedelme 2019-ben elérte a 73,64 milliárd eurót, ez 2001-hez képest több, mint 70\%-os növekedést jelentett. A térséggel folytatott tengeri kereskedelem fontosságát növeli a gazdaságilag elmaradottabb déli

14 Brian Pollinsí: Does Trade Still Follow the Flag? American Political Science Review, 83. (1989), 2. 465-480; Amir Najafi - Hossein Askari: The Impact of Political Relations Between Countries on Economic Relations. PSL Quarterly Review, Economia civile, 65. (2012), 62. 247-273.

15 Christina Davis - Sophie Meunier: Business as Usual? Economic Responses to Political Tensions. American Journal of Political Science, 55. (2011), 3. 628-646; Allison Carnegie: States Held Hostage: Political Hold-Up Problems and the Effects of International Institutions. American Political Science Review, 108. (2014), 1. 54-70.

16 Christina L. Davis - Andreas Fuchs - Kristina Johnson: State Control and the Effects of Foreign Relations on Bilateral Trade. Journal of Conflict Resolution, 63. (2019), 2. 405-438.

17 2014-ben például az Egyesült Államok és az Európai Unió gazdasági szankciókkal büntette Oroszországot az ukrajnai beavatkozás miatt, Oroszország pedig az európai mezőgazdasági termékek bojkottjával reagált. A kereskedelmi kapcsolatok politikai okokból történő manipulálása azonban nem csupán formális szankciókban ölthetnek testet: 2012-ben Argentínában az állami média (Telam) arról számolt be, hogy minisztériumi tisztségviselők körülbelül 20 vállalatot kértek arra, hogy ne importáljanak alapanyagot az Egyesült Királyságból válaszént a Falkland-szigetek kapcsán újból fellobbanó feszültségre; Vietnámban pedig a kormány - válaszul a dél-kínai-tengeri feszültségekre - arra ösztönözte a gyártó cégeket, hogy diverzifikálják az addig Kínából beszerzett importot. Kína 2010-ben a ritkaföldfémek Japánba való exportját állította le a Kelet-kínai-tengerhez köthető területi vitájuk következtében, majd egy időre felfüggesztette a Norvégiából érkező friss lazacimportot, miután a Nobel Bizottság a Nobel-békedíjat Liu Xiaobo kínai emberi jogi aktivistának ítélte. Davis-Fuchs-Johnson (2019) i. m. 406.

18 Global Edge: Italy - Trade Statistics.

19 TrendEconomy: Annual International Trade Statistics by Country-Italy. 2020.

20 Ministero degli Affari Esteri: The Italian Strategy in the Mediterranean. 2017. 
országrész fejlődéséhez való hozzájárulása. Amellett, hogy a nemzeti tengeri kereskedelem körülbelül fele az úgynevezett Mezzogiorno kikötőin keresztül folyik, a déli tartományok vállalkozásai kereskedelmi forgalmuk körülbelül 63\%-át tengeren keresztül bonyolítják, mintegy 53 milliárd euró értékben. ${ }^{21}$ Figyelembe véve az olasz gazdaság szerkezetét, azaz hogy az olasz vállalkozások döntő többsége a kis- és középvállalkozások közé tartozik, a MENA-régió közelsége megfizethető áron nyújt számukra üzleti lehetőséget. Az olasz cégek líbiai jelenlétét és a líbiai piacra való belépését elősegíti bilaterális kapcsolatok történelmi jellege, valamint a líbiai gazdaság diverzifikációra való rászorultsága is.

2011-ig Líbia volt az észak-afrikai térség leggyorsabban fejlődő országa, amelynek fejlődési mutatói a hasonló gazdasági szerkezetű Omán és Szaúd-Arábia mutatóival konvergáltak; 2008 és 2010 között az egy före eső líbiai GDP 30000 dollár körül volt, ami az algériai és egyiptomi GDP háromszorosa volt, de gazdagabb kőolaj-kitermelőknél (például Omán és Szaúd-Arábia) alacsonyabb volt. 2011-ben a líbiai GDP bezuhant, 2019-ben már csak 7800 dollár körül volt. ${ }^{22}$ Líbia az úgynevezett rentier state-ek közé sorolható, gazdasága és jóléte az energiahordozók exportjából származó jövedelemtől függ. A központi bevételek 96\%-a az energiahordozókból származik, ez adja a teljes líbiai export 98\%-át. ${ }^{23}$ A Világbank becslése szerint a Covid-járvány, a belső konfliktusok, a csökkenő olajárak és az energiahordozók kitermelésének csökkenése miatt a líbiai gazdaság teljesítménye körülbelül 31\%-kal csökkent 2020-ban. ${ }^{24}$

Líbia nem tartozik Olaszország top30 kereskedelmi partnere közé. 2016-2018 között az import 0,5-1\%-a származott Líbiából, export terén pedig az első 30 partnerország között nem volt ott Líbia. ${ }^{25}$ Az olasz import 2011 óta 2016-ot kivéve mindig jelentősen meghaladta a Líbiába irányuló export mennyiségét, ez elsősorban a kőolaj- és földgázimport miatt van. Az olasz import döntő része (körülbelül 98\%-a) kőolaj és földgáz, a maradék főként vasércből közvetlen fémkiválasztással nyert vastermékek $(0,367 \%)$, arany $(0,046 \%)$, aciklikus alkohol $(0,041 \%) .{ }^{26}$ Ezek alapján a Líbiából Olaszországba irányuló import - eltekintve a külön szakaszban tárgyalt energiahordozóktól - más forrásból is pótolható termékekből áll össze, mennyiségük pedig nem jelentős. Olaszország Líbiába legnagyobb mértékben feldolgozott kőolajat ${ }^{27}$ szállít, ez teszi ki az export 44\%-át, kisebb részben paradicsomot (4,68\%), szigetelt huzalokat és kábeleket $(2,82 \%)$, szerelvényeket (2,21\%), egyéb élelmiszereket (3\%), gyógyszert (1,34\%).

21 SRM Maritime Economy: Italian Maritime Economy: China, Energy corridors, ports and new routes: geomaps of a changing Mediterranean (2018. június 5.)

22 Tullio Buccellato - Matteo Pignatti: Libia: servono stabilità e sviluppo per un partner chiave dell'Italia. Centro Studi Confindustria, 2019. augusztus 6.; WorldBank: Libya.

23 QualEnergia: Rapporti Libia-Italia, il peso di gas e petrolio. QualEnergia, 2016. március 8.

24 WorldBank: The World Bank in Libya - Overview.

25 Fabio Giorgio (szerk.): Statistiche relative all'import/export di merci dell'Italia. Osservatorio Economico, Ministero dello Sviluppo Economico, 2019.

26 TrendEconomy: Annual International Trade Statistics by Country-Italy-Libya. 2020.

27 Köolajból és bitumenes ásványokból előállított olaj, a nyers kivételével; másutt nem említett olyan készítmény, amely legkevesebb 70 tömegszázalékban kőolajat vagy bitumenes ásványokból előállított olajat tartalmaz, és amelynek ez az olaj a lényeges alkotórésze; olajhulladék, ez lényegében az ENI által Líbiában kitermelt energiahordozók feldolgozás utáni visszaexportálása. 


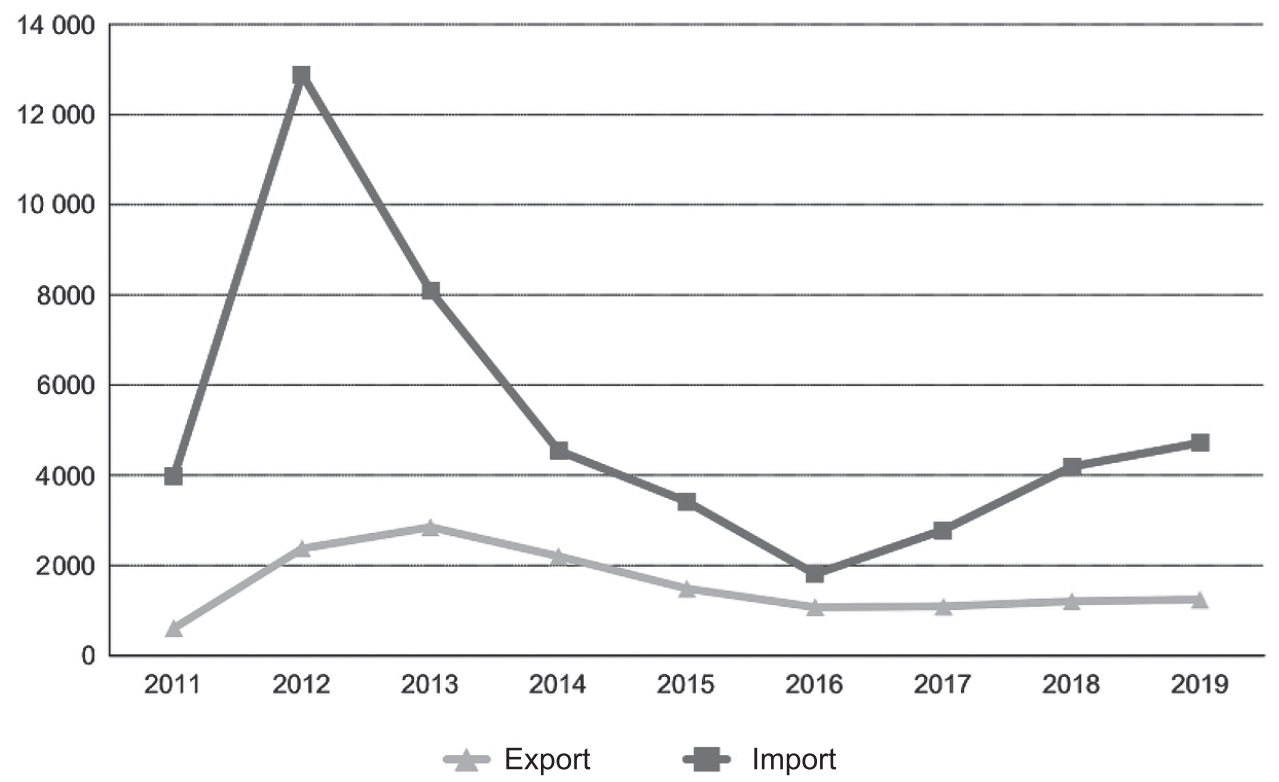

1. ábra: Olaszország Líbiába irányuló exportja, és onnan behozott importja 2011-2019 között, millió euró Forrás: Italian Trade \& Investment Agency: Interscambio commerciale dell'Italia per paesi: Libia, 2020

Bár jelenleg nem a Líbiába irányuló olasz export képezi az olasz külkereskedelem gerincét, az exportfejlesztésre számos lehetőség van. Az olasz vállalatok az infrastrukturális szektorban, az olajfúrás és -kitermelés területén járulhatnak hozzá érdemben a líbiai gazdaság fellendítéséhez. Egyes becslések szerint az újjáépítési munkálatokban a következő tíz évben akár 30 milliárd euró értékű munkát tudnának elvégezni. A hasonló gazdasági berendezkedésü, rentier state államokkal való kereskedelmi mutatókból kiindulva a Confindustria olasz szakszervezet becslései szerint, ha Líbia visszatérne egy Algériához hasonló fejlődési útra, és Olaszország az exportját függetlenítené a szénhidrogénektől, a made in Italy termékek Líbiába való exportjában akár évi egymilliárd eurónyi potenciál lenne. Ezen gazdasági lehetőségek kiaknázása miatt (is) érdeke Olaszországnak a líbiai stabilizálás előmozdítása, hiszen akár évi 4 milliárd euróval nagyobb forgalmat tudnának lebonyolítani a vállalatok. Figyelembe véve a líbiai újjáépítésben való potenciális részvételt, az infrastrukturális befektetéseket ${ }^{28}$, illetve a líbiai lakossági fogyasztásra is történő kőolaj- és földgázkitermelést, ez egyben nagyobb befolyást biztosítana Olaszország számára az energiabiztonság és a migráció szempontjából kiemelkedő fontosságú országban. ${ }^{29}$

Az olasz-líbiai kereskedelmi kapcsolatok vizsgálatánál célszerű a Líbiába irányuló olasz export változását szélesebb földrajzi kontextusban is ábrázolni. Ahogy a 2. ábrából

28 2008-ban a bengázi szerződésbe belefoglalták, hogy Olaszország Tripolit és Bengázit összekötő tengerparti autópályát épít Líbiában egyfajta kártérítésként, de ennek építése akkor nem valósult meg. 2020 őszén ismét ígéretet tettek megépítésére, illetve ekkor bejelentették a tripoli reptér újjáépítését is. Simone Canettieri: Di Maio va in Libia e rilancia l'autostrada di Berlusconi e Gheddafi. Il Foglio, 2020. szeptember 1.

29 Buccellato-Pignatti (2019) i. m. 
látszik, hogy 2000-től az arab tavaszig nagyjából azonos fejlődési ívet járt be a Líbiába, valamint az Egyiptomba és Algériába, mint hasonló kiterjedésű szomszédos országokba, illetve Szaúd-Arábiába, mint hasonló fejlődési mutatókkal rendelkező olajkitermelő országba irányuló olasz export. 2011 óta a politikai instabilitás miatt töredékére csökkent a Líbiába irányuló olasz export, ennek ideiglenes növekedése nagyjából hasonló ívet ír le a líbiai GDP változásával. ${ }^{30}$ Ahogy a grafikonon látható, szintén csökkenő tendenciát mutat az egyiptomi export - az ábrázolt országok közül Líbia után itt volt a legnagyobb a politikai instabilitás a kérdéses időszakban, itt azonban a csökkenés nagyjából egyenletes, nem olyan zuhanásszerü, mint Líbia esetében.

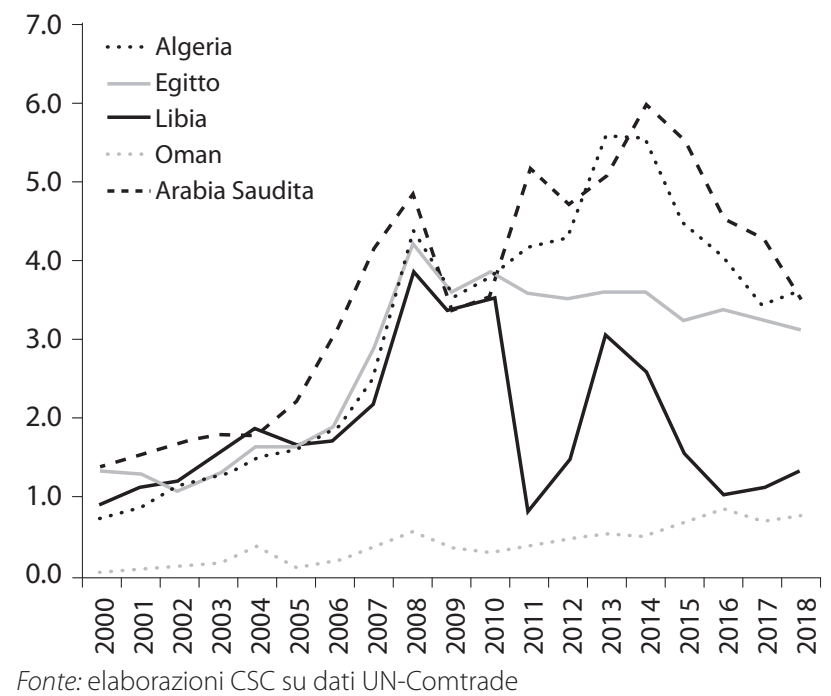

2. ábra: Algériába, Egyiptomba, Libiába, Ománba és Szaúd-Arábia irányuló olasz export 2000-2018 (milliárd dollár) Forrás: Buccellato-Pignatti (2019) i. m.

A líbiai kereskedelmi mutatókat vizsgálva az látszik, hogy Líbia számára Olaszország a top kereskedelmi partnerek közé tartozik import és export téren is, bár gazdasági téren általánosságban megmutatkozik Róma előnyének csökkenése és Kína térnyerése, utóbbi összhangban Kína afrikai terjeszkedésével. ${ }^{31}$ Ahogy a 3. és 4. ábrán a statisztikák mutatják, Olaszország volt a líbiai export fö célországa és a líbiai import fő származási országa is körülbelül 2015-2016-ig. Míg 2010-ben a líbiai export 42\%-a Olaszországba irányult (15,5 milliárd dollár értékben), a második helyen Franciaország szerepelt 15,5\%-kal, ${ }^{32}$ addig 2019-re eltünt az olasz dominancia, az arab tavasz előtti értékek megközelítése nem tünik reálisnak. A líbiai import területén Olaszország nem tudta megőrizni a vezető szerepét, itt Törökország és Kína egyre jobban megelőzi

\footnotetext{
30 Buccellato-Pignatti (2019) i. m.

31 Lásd például Vecsey Mariann: A Sárkány Afrikában. In Hamar Imre - Besenyő János (szerk.): Kína a globális kihívások tükrében. China In the Light of Global Challenges. Budapest, ELTE Konfuciusz Intézet, 2018. 207-219.

32 TrendEconomy: Annual International Trade Statistics by Country-Libya. 2020.
} 
Olaszországot, és a növekvő emirátusi export is 2019-ben majdnem elérte az olasz szintjét.

\section{A líbiai export fő célországai 2010-2019}

(milliárd dollár)

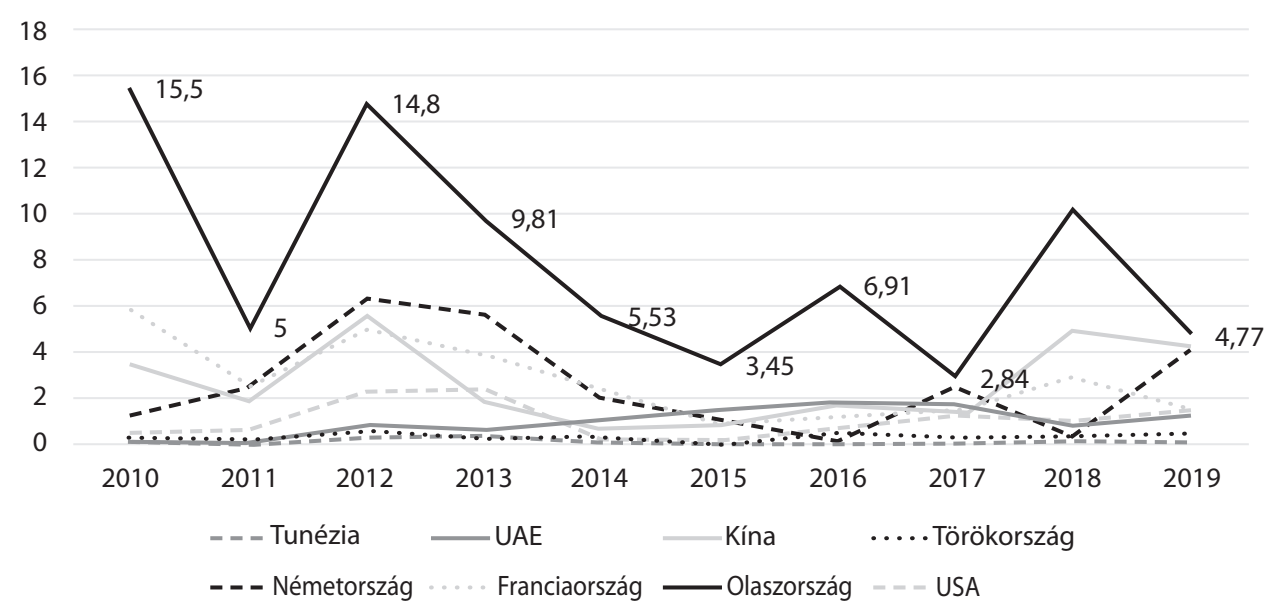

3. ábra: A líbiai export célországai 2010-2019

Forrás: Obervatory of Economic Complexity: What does Libya export alapján saját szerkesztés

\section{A líbiai import fő származási országai 2010-2019} (milliárd dollár)

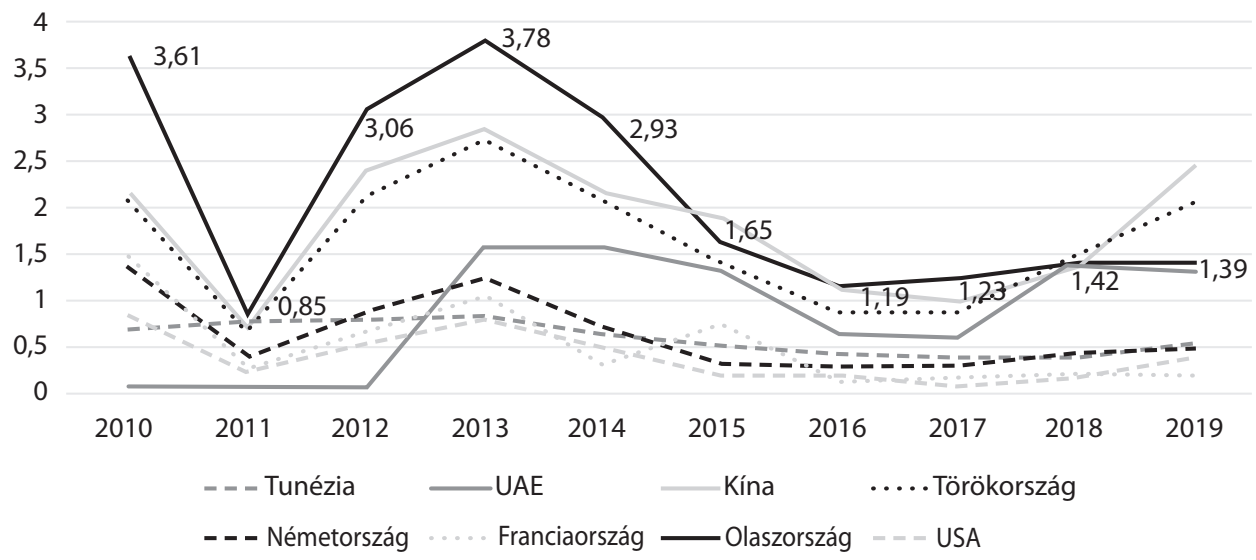


A líbiai kereskedelmi statisztikák kapcsán ki kell emelni, hogy az export és az import terén is jelentős volt Olaszország előnye az arab tavasz előtt. Az előny mértékének értékelésekor figyelembe kell venni, hogy ez már Líbia nemzetközi rendszerbe történő reintegrációja utáni helyzet volt. Ekkor új és régi-új szereplők jelentek meg a líbiai piacon, azaz az elszigetelődés előtt és alatt Olaszország szerepe még nagyobb volt a líbiai gazdaságban. Miután Líbia ismét a nemzetközi közösség elfogadott tagja lett, olyan új, tőkeerős országok lettek „hirtelen" Olaszország vetélytársai, mint Kína, Törökország, India, Korea vagy az Öböl-államok, amelyek a tőke mellett biztosítani tudták az alacsony költségű munkaerőt is. Gyakori jelenség volt azonban, hogy az új versenytársak - elsősorban az Öböl-államok - olyan területekbe fektettek be (például pénzügy, ingatlanok), amelyeket a 2008-as gazdasági válság meggyengített, vagy nem feleltek meg teljesen a líbiai gazdaságfejlesztési „, igényeknek". ${ }^{33}$ Ez azt eredményezte, hogy a líbiai import-export területén Olaszország megőrizte ugyan vezető szerepét, de a versenytársaihoz képest elönye csökkent.

Az exportban és az importban bekövetkező változások ábrázolása mellett célszerü megjeleníteni azt is, hogy a Líbiában jelentős szerepet betöltő külföldi országok piaci részesedése milyen változáson ment keresztül.

Külföldi szereplők líbiai piaci részesedése 2010-2019

(százalékos arányban)

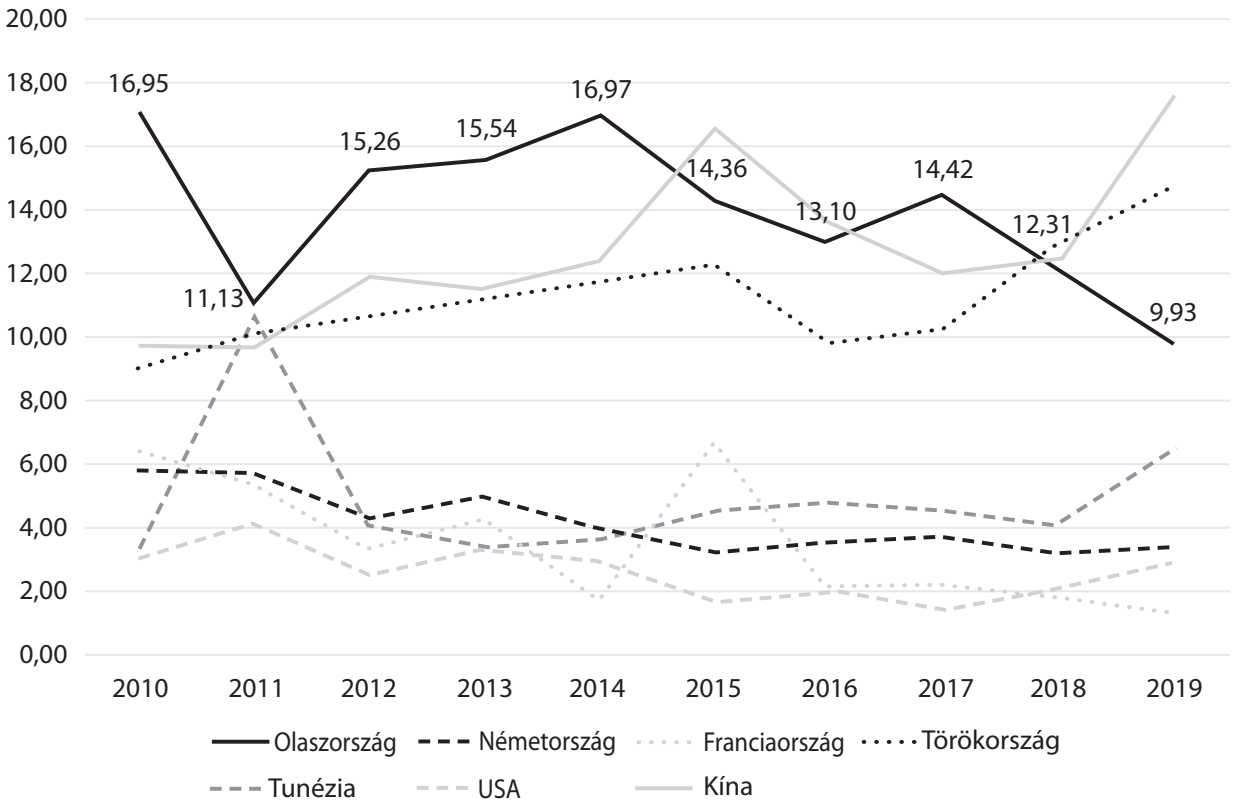

5. ábra: Külföldi szereplök líbiai piaci részesedése 2010-2019

Forrás: ISTAT: Commercio estero e attivitá internazionali delle imprese, 2020. alapján saját szerkesztés Megjegyzés: A könnyebb ábrázolhatóság érdekében csak a rangsor elején levő államokat vettük figyelembe. A többi állam az ábrázoltaknál kisebb részesedést tudhat a magáénak.

33 Franco Zallio: Le deboli onde della crisi. Politica Internazionale, 34. (2009), 1/3. 145-155. 
A fentiek alapján Olaszország számára a Líbiával való gazdasági kapcsolatok fontosságát elsősorban az adja, hogy bár nem Líbia az ország fő gazdasági partnere sem az export, sem az import terén (eltekintve az energiahordozóktól), Olaszország vezető piaci szereplő volt Líbiában az arab tavasz előtt, ami a biztonság szektorainak szoros összekapcsolódása és egymásra gyakorolt hatása miatt más téren (például politikai kapcsolatok) is éreztette hatását. Kadhafi alatt a szoros politikai kapcsolatok egyértelműen a gazdasági kapcsolatok megerősödését hozták magukkal. ${ }^{34}$ Bár a fő versenytársakhoz képest a piaci részesedése romlott, már nem Róma a legjelentősebb külföldi szereplő, továbbra is az elsők között van. Pusztán a gazdasági kapcsolatokat vizsgálva Líbia jobban rá van szorulva Olaszországra, mint fordítva, a hatalmi aszimmetria ezen a téren Olaszország irányába billen el.

A líbiai állam rentier state jellege miatt a gazdasági kapcsolatok a líbiai olaj kitermelésének ötvenes években történő megkezdése ${ }^{35}$ óta a legélesebb politikai feszültségek idején is megmaradtak, sőt Líbia nemzetközi elszigeteltsége idején még erősödtek is, figyelembe véve, hogy ebben az időszakban Olaszország maradt Líbia legkomolyabb partnere. Líbia nemzetközi rendszerbe történő reintegrálódása gazdasági és energetikai szempontból Olaszország líbiai értékének csökkenését hozta magával, annak ellenére, hogy abszolút számokban Olaszország nyert a líbiai piacok megnyitásával és fellendülésével. A korábbi kölcsönösség meggyengült, mert a kőolaj iránt globális szinten nőtt a kereslet, és nyitott piacok mellett könnyebben lehetett Olaszországot mint legnagyobb importőrt helyettesíteni. Líbia kereskedelmi partnerei diverzifikálódtak. Különböző szereplők léptek be újonnan (például Kína), vagy hosszabb szünet után újra (például Oroszország, Franciaország, Nagy-Britannia, USA, Spanyolország) a líbiai energetikai piacra. ${ }^{36}$ A Kadhafi-rezsim a megnövekvő olajbevételekböl megkezdte a gazdaság progresszív privatizálását, enyhe reformokat vezetett be, amelyek keretében az energetikai szektoron kívül is gazdaságélénkítési céllal beengedett külföldi befektetőket az országba. Mivel így szükségszerüképp a fejlett országokra kellett támaszkodni, célszerü volt az Olaszországgal való együttmüködést erősíteni, hiszen ebben az esetben a kétoldalú kapcsolatok már egy kialakított keretben folytak. A líbiai demográfiai folyamatok és következményei (nagy népességnövekedés és magas fiatalkori munkanélküliség stb.), valamint a piacok és a szabadkereskedelem felé való nyitás miatt megnőtt a kereslet a kis- és közepes vállalkozásokra. Ebből a szempontból Olaszország kompetitív előnye a versenytársakhoz képest nemcsak abban rejlett, hogy az olasz vállalatok régebb óta jelen voltak Líbiában, így nagyobb intézményi és kapcsolati tőkét birtokoltak, hanem a líbiai igényeket jobban kielégítő, kkv-kra épülő olasz gazdasági struktúrában is. ${ }^{37} \mathrm{~A}$ líbiai igény és kereslet megléte ellenére azonban az önálló Líbia megalakulásáig visszanyúló folyamatos jelenlét ellenére az olasz kkv-k folyamatos problémákkal szembesültek

34 Arturo Varvelli: Italy and Libya: Renewing a Special Relationship. The International Spectator, 45. (2010a), 3. 117-130.

35 Sofia Van Genugten: Libya in western foreign policies, 1911 to 2011. London, Palgrave MacMillan, 2016. 72-73, és Leonardo Maugeri: L' arma del petrolio. Questione petrolifera globale, guerra fredda e politica italiana nella vicenda di Enrico Mattei. Firenze, Loggia dè Lanzi, 1994. 142-145.

36 Varvelli (2010a) i. m. 123.

37 OECD: „SME and entrepreneurship issues and policies in Italy: Assessment and recommendations”, in Italy: Key Issues and Policies. Párizs, OECD Publishing, 2014. 
Líbiában a komplex befektetési szabályoktól a kifizetési problémákon át a gyakori rendezetlen vitákig, és nem rendelkeztek megfelelő eszközökkel az érdekeik érvényesítéséhez. ${ }^{38}$

A gazdasági kapcsolatok kapcsán röviden említést kell tenni a befektetésekröl: 2008-ban aláirt bengázi szerződés ${ }^{39}$ megnyitotta az utat, hogy líbiai állami befektetési alapok stratégiai olasz vállalatokba vásárolják be magukat. A szerződés aláírása utáni egy évben a Líbiai Központi Bank (Libyan Central Bank) 64,6 millió dollár értékben vásárolt az ENI részvényeiből, és kifejezte a $10 \%$-os felvásárlás iránti igényét, amelynek következtében az ENI részvényeinek értéke majdnem 15\%-kal növekedett. ${ }^{40}$ A Líbiai Külkereskedelmi Bank (Libyan Foreign Bank) a Banca UNAE SpA 67,5\%-át vásárolta fel, az UniCredit 7,5\%-át, ez utóbbi - mivel az UniCredit Olaszország második legnagyobb bankja - különösen fontos befektetés volt, mert a 2008-as gazdasági válság után biztosított likviditást a banknak. ${ }^{41} \mathrm{~A}$ Líbiai Befektetési Ügynökség (Libyan Investment Authority - LIA) felvásárolta többek között a Finmeccanica $2 \%$-át, a Juventus futballcsapat 7,5\%-át és a FIAT $2 \%$-át, ${ }^{42}$ valamint érdeklődést mutattak a Telekom (telekommunikációs szektor), az Impregilo (építőipar), Terna (energetika) és a Generali (biztosítás) irányába is. A bengházi szerződés aláírása után Olaszországba irányuló líbiai befektetések célpontjai alapján az állapítható meg, hogy a líbiai befektetési alapok olyan szektorokat céloztak meg (energetika, bankszektor, pénzügyi és infrastrukturális szektor), amelyek a líbiai fejlődés szempontjából potenciálisan stratégiai szektorrá válhattak volna, ha az arab tavasz nem mozdítja más fejlődési pályára Líbiát. ${ }^{43}$ Bár ezeket a befektetéseket 2011-ben az ENSZ-szankciók befagyasztották, ki kell emelni, hogy Kadhafi halála előtt a LIA Olaszországban fektetett be a legnagyobb értékben. Olasz szempontból a líbiai FDI nem a mértéke miatt fontos, hanem azért, mert stratégiai jelentőségű vállalatokba fektette be a Kadhafi-rezsim. Líbia ezeken a befektetéseken olyan erősen jelen volt az olasz gazdaságban, hogy az arab tavasz kezdetén, a tüntetések erőszakossá válása után, 2011. február 21-én az olasz tőzsde 3,6\%-ot esett. ${ }^{44}$

38 Varvelli (2010a) i. m. 125

39 A bengázi szerződés 2018. augusztusi aláírása fordulópont a két ország kapcsolataiban, a kilencvenes évek végén megkezdődött politikai konszolidáció megerősítéseként tekinthetünk rá. A szerződés aláíásával egyszer s mindenkorra lezárták „az olasz gyarmati múlt fájdalmas fejezetét, és új együttműködési területeket határoztak meg”. A politikai viták bengázi szerződéssel való rendezése a két ország közti különleges kapcsolat megújitásához vezetett, hiszen Róma bármely más európai országnál szorosabb kapcsolatot tud(ott) kialakítani Líbiával, s ez lehetővé tette Olaszország számára, hogy a szerződés aláírása után a líbiai gazdaságban betöltött vezető szerepét megerősítse. Nicolo Ronzitti: The Treaty on Friendship, Partnership and Cooperation between Italy and Libya: New Prospects for Cooperation in the Mediterranean. Bulletin of Italian Politics, 1. (2009). 125-133.

40 Claudia Gazzini: Assessing Italy's Grande Gesto to Libya. Middle East Research and Information Project, 2009. március 16.

41 Varvelli (2010a) i. m. 127.

42 Ben Lombardi: The Berlusconi Government and Intervention in Libya. The International Spectator: Italian Journal of International Affairs, 46. (2011), 4. 38.

43 Arturo Varvelli: Relazioni economiche italo-libiche. Osservatorio di Politica Internazionale, Nota di analisi n. 5. 2008. december 17.

44 Lombardi (2011) i. m. 


\section{Energiabiztonság}

A hidegháború vége óta az energiabiztonság garantálása az addig uralkodó belső, technikai megközelítés helyett külső dimenziót kapott, ${ }^{45}$ előtérbe kerültek az exportáló országokkal való külkapcsolatok és a geopolitikai szempontok, ez az energiahordozókkal gyengén ellátott, importfüggő Olaszország külpolitikájában is hangsúlyos elem lett. Politikailag az energiaellátás biztosítása kölcsönös érdekek meglétét igényli egyenlö felekként fellépő, exportőrök és fogyasztók (importőrök) között. A külpolitika épp ezért egyre fontosabb szerepet játszik az energiapolitikában. Líbia esetén ez fordítva is igaz: az ENI fontos szerepet játszik Róma külpolitikai érdekérvényesítésében, mert amíg Olaszország befolyása csökkent az arab tavasz óta, az ENI megőrizte vezető pozícióját.

Olaszország energiabiztonsága szempontjából az észak-afrikai régió fontos szerepet tölt be, hiszen a térség államai az arab tavasz előtt kőolajexport körülbelül 35-38\%-át, a földgázexport körülbelül 40-45\%-át biztosították Olaszországnak, az észak-afrikai államok számára pedig Olaszország egyrészt fontos gazdasági felvevőpiac, másrészt pedig az olasz vállalatok know-how transzferje, és fejlesztései hozzájárulnak a vegyipar és általánosságban a gazdaság fejlődéséhez. ${ }^{46}$

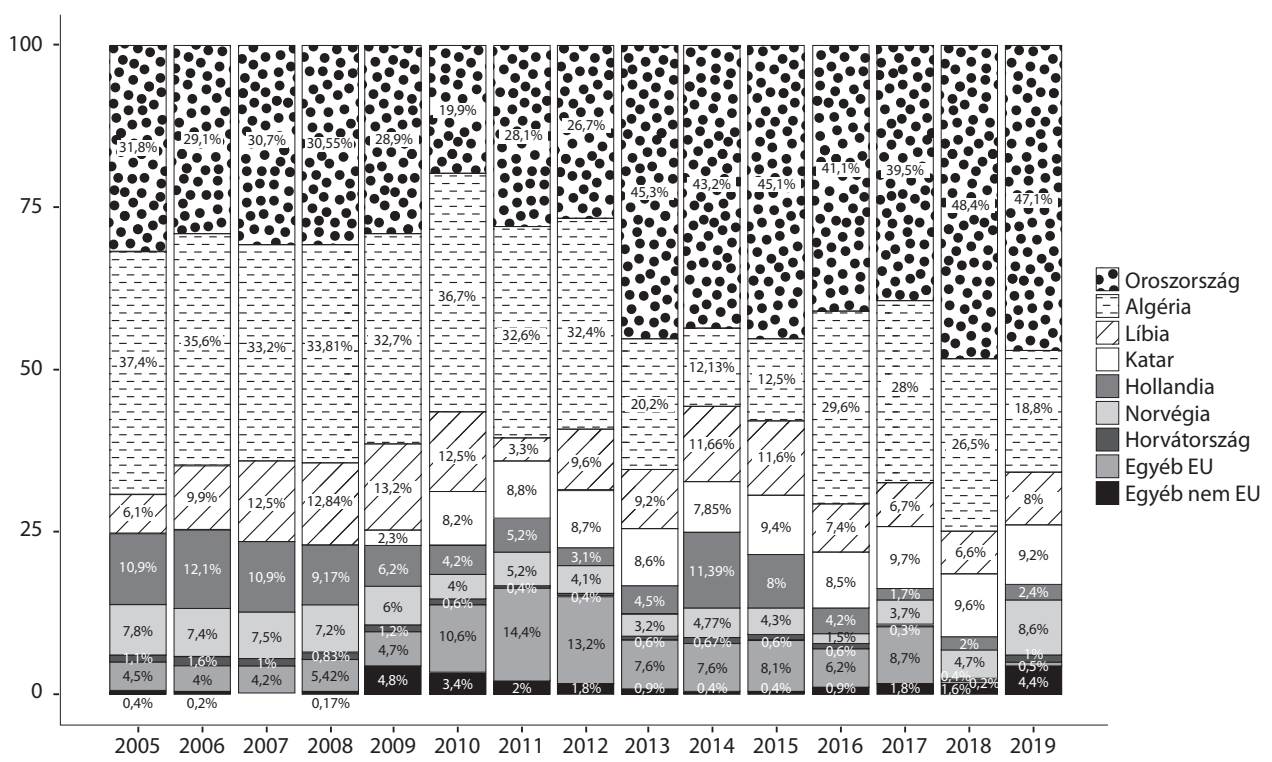

6. ábra: Az Olaszországba exportált földgáz ország szerinti megoszlása 2005-2019

Forrás: Ministero dello Sviluppo Economico: Analisi e statistiche energetiche a minerarie - Gas naturale, importazioni és Unione Petrolifera: Pubblicazioni alapján saját szerkesztés

45 Arturo Varvelli: Le strategie di politica energetica dell'Italia. Criticità interne e opportunità internazionali. Quaderni di Relazioni Internazionali, 22. (2010b). 98-114.

46 Nicolo Sartori: Il Mediterraneo e la sicurezza energetica. In Alessandro Marrone - Michele Nones (szerk.): La sicurezza nel Mediterraneo e l'Italia. Róma, Quaderni IAI, Edizioni Nuova Cultura, 2015. 53. 
A földgázellátás kapcsán (6. ábra) kiemelendő a növekvő függés Oroszországtól (2018ban 48,4\%), és bár a Líbiából érkező földgáz aránya mindig is kisebb volt, mint a kőolaj aránya, a földgázszállítás sem érte el az arab tavasz előtti szintet. A líbiai földgáz exportálása csővezetéken (Greenstream) történik, kizárólag Olaszországba, hiszen az egyetlen LNG cseppfolyósító üzem (Marsa al-Bregaban) 2011 óta nem müködik. ${ }^{47}$

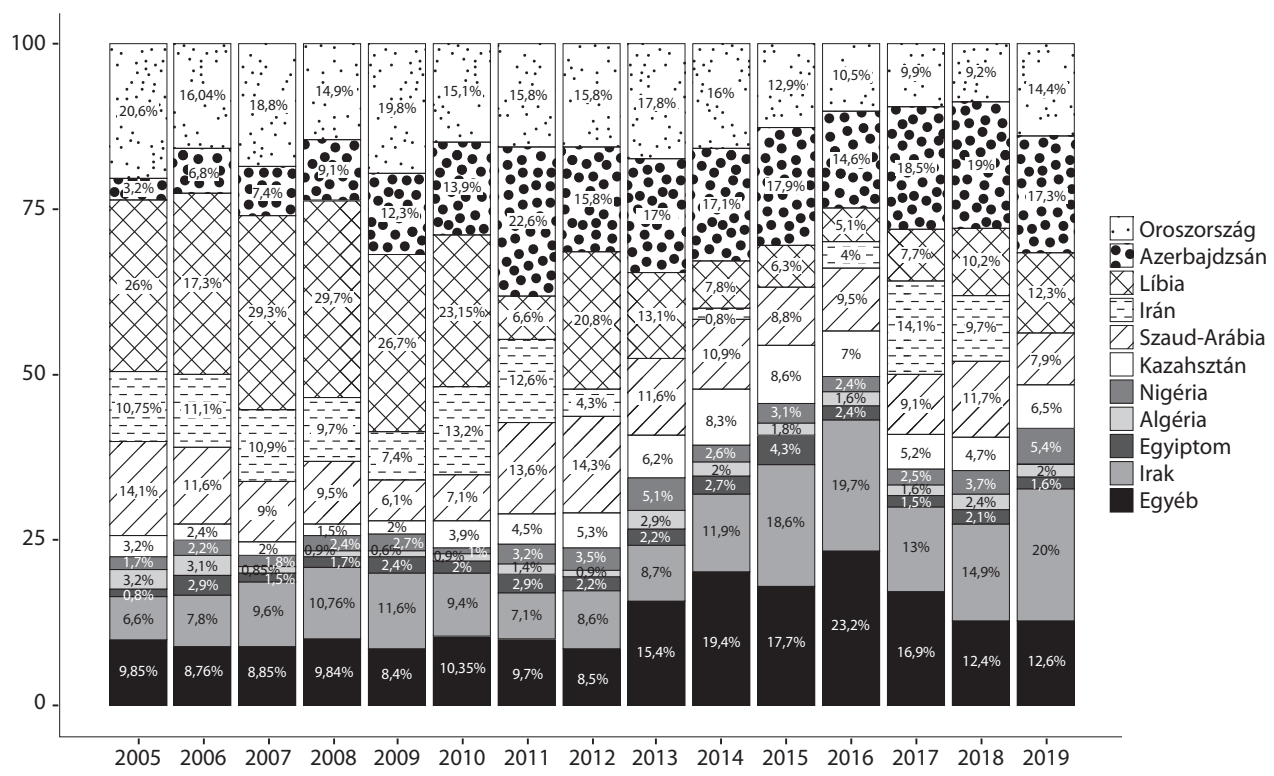

7. ábra: Az Olaszországba exportált köolaj ország szerinti megoszlása 2005-2019

Forrás: Ministero dello Sviluppo Economico i. m. és Unione Petrolifera i. m. alapján saját szerkesztés

Ahogy a 7. ábrán is látható, az arab tavasz előtt Líbiából érkezett a legtöbb kőolaj Olaszországba, a teljes export körülbelül egynegyede, ez azonban 2011-ben bezuhant. Bár Kadhafi halála után, 2011 végén és 2012-ben úgy tűnt, konszolidálódik a líbiai helyzet, ismét növekedett a Líbiából érkező kőolajexport aránya (körülbelül 20,8\%-ra), a líbiai belső konfliktusok elhúzódásával, a konfliktus proxysodásával párhuzamosan ismét csökkent, és az arab tavasz előtti időszakot azóta sem tudja megközelíteni. Az így kieső exportot Olaszország föként azeri, iráni és szaúd-arábiai olajjal igyekszik pótolni, de az arab tavasz óta kétszeresére nőtt az Irakból exportált olaj aránya is.

Ahogy a két statisztika mutatja, a kőolaj- és a földgázimport forrásait alapvetően sikeresen diverzifikálja Olaszország, hiszen más országokhoz hasonlóan Róma energiabiztonsági stratégiája is egy N-1 modellen alapul, amelynek lényege, hogy egy fontosabb, Olaszországba exportáló ország „kiesését” is hosszabb ideig pótolni képes. A sikeres diverzifikáció szempontjából fontos, hogy a legnagyobb importőr országok geopolitikailag különböző területeken feküdjenek, ez a kőolajellátás szempontjából

SRM: MED \& Italian Energy Report, Energy sources, flows and strategies of Italy between Europe an the Mediterranean, 2019. 
nagyjából megvalósul (Azerbajdzsán/Irak, Szaúd-Arábia/Líbia), és bár a négy legnagyobb földgázszállító ország három geopolitikai területen fekszik (Oroszország/Algéria, Líbia/Katar), Oroszországtól és Algériától függ az olasz földgázimport kétharmada. ${ }^{48}$ A Líbiából exportált földgáz sosem érte el az arab tavasz előtti mennyiséget, de az elmúlt években nagyjából stabilizálódott annak mennyisége. Amíg a líbiai helyzet nem rendeződik, nem várható, hogy a líbiai kitermelés - így az Olaszországba irányuló export - nagyságrendileg növekedne. Bár az energiaellátás diverzifikálva van, a Líbiából érkező kőolaj- és földgázimport szünetelése esetén - főként a földgázszektorban - Olaszország jobban ki lenne téve az orosz-ukrán konfliktusnak, valamint az algériai és tunéziai ${ }^{49}$ instabilitásnak is. Pont ez a bizonytalanság késztette/készteti Rómát egyrészt a diverzifikálásra (Irak, Azerbajdzsán, Oroszország), másrészt geopolitikailag Líbia stabilitásának előmozdítására. ${ }^{50}$

A mediterrán térségből érkező gáz két fő infrastruktúráját egyrészt Algériából Tunézián keresztülmenő Transmediterrán (Transmed) gázvezeték alkotja, amely az algériai olajmezőket köti össze Mazara del Vallóval (Szicília), évi 30 milliárd köbméteres kapacitásával európai szinten az egyik legjelentősebb vezeték. ${ }^{51}$ Másrészt pedig a Szicíliai-csatornán halad át a Földközi-tenger leghosszabb vezetéke, az 520 km hosszú Greenstream, amely a líbiai Wafa és Bahr Essalam olaj- és gázmezőkről indulva évi 8 milliárd köbméter földgázt szállít Olaszországba, a szicíliai Gelanál csatlakozva az olasz nemzeti hálózatba. ${ }^{52}$ A diverzifikáció és a térség stabilitásának előmozdítása azért is Olaszország nemzeti érdeke, mert ezt az infrastruktúrát - és ezáltal közvetetten Olaszország energiabiztonságát - sebezhetővé teszi a térség politikai instabilitása. Líbia esetében ez már konkrétan megmutatkozott, elég csak a Greenstream tevékenységének 2011-es, körülbelül nyolc hónapig tartó, ideiglenes felfüggesztésére ${ }^{53}$ gondolni: a 2010-ben körülbelül 9400 millió köbméter gáz érkezett Líbiából Olaszországba, 2011-ben csak 2239 millió. ${ }^{54} \mathrm{Az}$ ENI volt a legnagyobb külföldi olajvállalat Líbiában, itteni kőolaj- és földgáz-kitermelése (körülbelül 244000 millió hordó/év) globális tevékenységének körülbelül $14 \%$-át tette ki. ${ }^{55}$

Az ENI jelenleg 67 országban van jelen, forrásainak 52\%-a Afrikában található. A líbiai kitermelés $45 \%$-át végzi, ez az ENI globális tevékenységének $16 \%$-át teszi ki. ${ }^{56}$

Líbia rentier state mivolta miatt a központi hatalom (amennyiben ez a jelenlegi Líbia esetén értelmezhető fogalom) a jövőben is rá lesz szorulva az exportra. Ebből a szempontból az ENI közel hét évtizedes líbiai jelenléte során kialakított helyi kapcsolatrendszere és beágyazottsága, az ENI-hez köthető infrastruktúra (például Greenstream), valamint a tény, hogy az ENI a líbiai konfliktus során folyamatosan biztosította a belső fogyasztásra szánt földgáz kitermelését, megalapozza az ENI

48 SRM (2019) i. m. 70-73.

49 Ezeken az országokon mennek keresztül az Olaszország ellátása szempontjából fontos vezetékek.

50 Matteo Bressan: Sicurezza nazionale ed energetica. Perché per l'Italia la posta in gioco in Libia è alta. Formiche, 2019. április 15.

51 TRANSMED: Gas Transportation System.

52 ENI: Fact Book 2018. 69.

U.S. Energy Information Administration: Country Analyses Brief: Libya, 2014.

Statista: Volumes of natural gas imported from Libya to Italy from 2010 to 2018.

5 Sartori (2015) i. m.

56 Goffredo Galeazzi: L'Italia e il grande gioco del petrolio. Il Manifesto, 2020. január 15. 
jövőbeli szerepét Líbiában. Ugyanezen indokok alapján az ENI fontos eszköz a pozitív olasz országimázs líbiai visszaállításához, amelyet korábban a gyarmati időszak tépázott meg, majd az, hogy Olaszország - bár nemzetközi koalíció részeként, de - aktívan részt vett a 2011-es katonai intervencióban.

Az energiaszállítás diverzifikálása ellenére Olaszországnak továbbra is szüksége van a líbiai kőolajra és földgázra, ezt azonban - ahogy 2011 óta teszi - szükség esetén más forrásból pótolni tudja. A líbiai állam azonban az energiahordozókból származó bevételt nem tudja más forrásból pótolni. Bár szükség esetén az ENI líbiai tevékenységét át tudnák venni a versenytársai, kiemelendő, hogy a külföldi energiavállalatok közül az ENI jelenléte nyúlik vissza a legmesszebbre, illetve az is, hogy földgáz csak a Greenstreamen keresztül hagyja el Líbiát. Az energetika terén tehát nincs olyan erős aszimmetria, mint a kereskedelmi kapcsolatokban, mindkét fél számára ugyanis jelentős költségekkel járna a másik fél "lecserélése".

\section{Konklúzió}

A Líbiába irányuló olasz export aránya elenyésző a teljes olasz exporthoz képest, mégis, ezzel Olaszország Líbia számára a top importőrök közé tartozik. Olaszország kis- és középvállalkozásokra épülő gazdasága számára a földrajzi közelség miatt a líbiai piac számos lehetőséget rejt, ezt azonban a törékeny, polgárháborús líbiai helyzet miatt az olasz vállalatok nem tudják teljeskörűen kihasználni. Bár az ország líbiai piaci részesedése csökkent, már nincs meg az az előnye a többi országhoz képest, mint ami az arab tavasz előtt megvolt, továbbra is a líbiai gazdaság fontos szereplője, valamint a líbiai export fö célországa. Ezen a téren tehát - nem vizsgálva az energiahordozókat - egyértelműen jelen van a gazdasági aszimmetria Líbia és Olaszország között.

Ezt a nagyon jelentős egyenlőtlenséget árnyalják az energiahordozók, amelyeket Líbia rentier state mivolta miatt nem lehet figyelmen kívül hagyni. Olaszország alapvetően sikeresen diverzifikálta az energiahordozóinak importját, a mediterrán térség azonban továbbra is kiemelt szerepet játszik ebben, az ENI fontos koncessziókat tudhat magáénak a régióban. A Líbiából érkező kőolaj és földgáz mennyisége nem érte el az arab tavasz előtti szintet, ezt azonban sikeresen tudja Róma más forrásból pótolni, mindazonáltal - elsősorban a földgáz terén - az Oroszországtól való függés erősödött. Az ENI líbiai szerepének erősítése és érdekeinek védelme nemcsak a kőolaj és földgázszállítások biztosítása miatt fontos, hanem azért, mert évtizedek óta az ENI a legmeghatározóbb külföldi energiavállalat Líbiában, így a líbiai olasz befolyás egyik sarokpontja, amely akkor is meg tudta őrizni vezető szerepét, amikor Olaszország vesztett a 2011-es rezsimváltás után. Ennek következtében az energiahordozók terén nincs olyan egyértelmü aszimmetria az olasz-líbiai kapcsolatokban, mint a kereskedelem terén: az ENI tevékenységéből származó jövedelemre, valamint a líbiai lakossági fogyasztásra történő kitermelésre a mindenkori líbiai rezsimnek is szüksége van, Olaszország számára a kőolaj- és földgázszállítmányok biztosítása mellett az ENI a hatalmi befolyás egyik eszköze is. 
A tanulmány az Innovációs és Technológiai Minisztérium ÚNKP-20-3- II-NKE-37 kódszámú Új Nemzeti Kiválóság Programjának szakmai támogatásával készült.

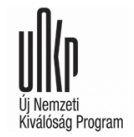

\section{Felhasznált irodalom}

Bressan, Matteo: Sicurezza nazionale ed energetica. Perché per l'Italia la posta in gioco in Libia è alta. Formiche, 2019. április 15. Online: https://formiche.net/2019/04/ libia-sicurezza-energia-posta-in-gioco/

Buccellato, Tullio - Matteo Pignatti: Libia: servono stabilità e sviluppo per un partner chiave dell'Italia. Centro Studi Confindustria, 2019. augusztus 6. Online: www. confindustria.it/home/centro-studi/temi-di-ricerca/scenari-geoeconomici/tutti/ dettaglio/Libia-partner-chiave-Italia

Buzan, Barry: People, States, and Fear: The National Security Problem in International Relations. Brighton, Wheatsheaf Books, 1983.

Canettieri, Simone: Di Maio va in Libia e rilancia l'autostrada di Berlusconi e Gheddafi. Il Foglio, 2020. szeptember 1. Online: www.ilfoglio.it/politica/2020/09/01/news/ di-maio-va-in-libia-e-rilancia-lautostrada-di-berlusconi-e-gheddafi-332428/

Carnegie, Allison: States Held Hostage: Political Hold-Up Problems and the Effects of International Institutions. American Political Science Review, 108. (2014), 1. 54-70. Online: https://doi.org/10.1017/S0003055413000646

Ceccorulli, Michela - Fabrizio Coticchia: 'I'll take two.' Migration, terrorism, and the Italian military engagement in Niger and Libya. Journal of Modern Italian Studies, 25. (2020), 2. 174-196. Online: https://doi.org/10.1080/1354571X.2020.1723291

Chelotti, Nicola - Elisabeth Johansson-Nogues: Stable unpredictability? An assessment of the Italian-Libyan relations. In Ludovica Marchi-Richard Whitman - Geoffrey Edwards (szerk.): Italy's foreign policy in the twenty-first century: a contested nature? London, Routledge, 2014. 178-196. Online: https://doi.org/10.4324/9781315745299-20

Colucci, Michele: Foreign immigration to Italy: crisis and the transformation of flow. Journal of Modern Italian Studies, 24. (2019), 3. 427-440. Online: https://doi.org /10.1080/1354571X.2019.1605721

Dassú, Marta - Maurizio Massari (szerk.): „Rapporto 2020 - Le scelte di politica estera. Unità di analisi e di programmazione". Ministero degli Affari Esteri, 2008. Online: www.esteri.it/mae/doc/Rapporto2020_SceltePoliticaEstera_090408.pdf

Davis, Christina - Sophie Meunier: Business as Usual? Economic Responses to Political Tensions. American Journal of Political Science, 55. (2011), 3. 628-646. Online: https://doi.org/10.1111/j.1540-5907.2010.00507.x

Davis, Christina - Andreas Fuchs - Kristina Johnson: State Control and the Effects of Foreign Relations on Bilateral Trade. Journal of Conflict Resolution, 63. (2019), 2. 405-438. Online: https://doi.org/10.1177/0022002717739087 
Demos \& PI: La percezione degli immigrati. 2017. november. Online: www.demos.it/ a01453.php

Di Filippo, Marcello - Anja Palm: Le sfide della politica migratoria e il nuovo corso di Minniti. In Greco, Ettore (szerk.): L'Italia al bivio. Rapporto sulla politica estera italiana. Róma, Edizioni Cultura, 2018. 65-80.

ENI: Fact Book 2018. Online: www.eni.com/assets/documents/documents-en/FactBook-2018-eng.pdf

Fereira, Susana: Human Security and Migration in Europe's Southern Borders. London, Palgrave Macmillan, 2019. Online: https://doi.org/10.1007/978-3-319-77947-8

Galeazzi, Goffredo: L'Italia e il grande gioco del petrolio. Il Manifesto, 2020. január 15. Online: https://ilmanifesto.it/litalia-e-il-grande-gioco-del-petrolio/

Gazzini, Claudia: Assessing Italy's Grande Gesto to Libya. Middle East Research and Information Project, 2009. március 16. Online: https://merip.org/2009/03/assessing-italys-grande-gesto-to-libya/

Giorgio, Fabio (szerk.): Statistiche relative all'import/export dimercidell'Italia. Osservatorio Economico, Ministero dello Sviluppo Economico, 2019. Online: www.mise.gov.it/ images/stories/commercio_internazionale/osservatorio_commercio_internazionale/statistiche_import_export/completo.pdf

Global Edge: Italy - Trade Statistics. Online: https://globaledge.msu.edu/countries/ italy/tradestats

Hirschman, Albert O: National Power and the Structure of Foreign Trade. Berkeley, University of California Press, 1945.

ISTAT: Commercio estero e attivitá internazionali delle imprese, 2020. Online: www. annuarioistatice.it/avvio.html

Istituto Affari Internazionali: Gli italiani e la politica estera. Rapporto di ricerca a cura di DISPOC/LAPS e IAI. 2017. Online: www.iai.it/sites/default/files/laps-iai_2017.pdf

Italian Trade \& Investment Agency: Interscambio commerciale dell'Italia per paesi: Libia, 2020. Online: www.ice.it/it/statistiche/Short_stat_view.aspx?TipoReport=1\&paese=Libia\&anno_fine_periodo $=2020 \&$ anno_fine_serie $=2019 \&$ mese_fine $=07$

Keohane, Robert O. - Joseph S. Nye,: Power and Interdependence: World Politics in Transition. Boston, Little Brown, 1977.

Lombardi, Ben: The Berlusconi Government and Intervention in Libya. The International Spectator: Italian Journal of International Affairs, 46. (2011), 4. 31-44. Online: https://doi.org/10.1080/03932729.2011.628090

Lutterbeck Derek: Migrants, weapons and oil: Europe and Libya after the sanctions. The Journal of North African Studies, 14. (2019), 2. 169-184. Online: https://doi. org/10.1080/13629380802343558

Maugeri, Leonardo: L' arma del petrolio. Questione petrolifera globale, guerra fredda e politica italiana nella vicenda di Enrico Mattei. Firenze, Loggia dè Lanzi, 1994.

Ministero degli Affari Esteri: The Italian Strategy in the Mediterranean. 2017. Online: www.esteri.it/mae/resource/doc/2017/12/med-maeci-eng.pdf

Ministero della Difesa: Documento Programmatico per la Difesa per il triennio 2019-2021. Online: www.difesa.it/Content/Documents/Documento_ Programmatico_Pluriennale_(DPP)_2019_2021_digit.pdf 
Ministero dello Sviluppo Economico, 2019. Online: www.mise.gov.it/images/stories/ commercio_internazionale/osservatorio_commercio_internazionale/statistiche_ import_export/completo.pdf

Ministero dello Sviluppo Economico: Analisi e statistiche energetiche a minerarie - Gas naturale, importazioni. Online: https://dgsaie.mise.gov.it/gas_naturale_importazioni.php

Ministero dello Sviluppo Economico: Analisi e statistiche energetiche a minerarie - Situazione energetica. Online: https://dgsaie.mise.gov.it/situazione_energetica.php?lang=it_IT

Najafi, Amir - Hossein Askari: The Impact of Political Relations Between Countries on Economic Relations. PSL Quarterly Review, Economia civile, 65. (2012), 262. 247-273. Online: https://ideas.repec.org/a/psl/pslqrr/201233.html

Nye, Joseph S.: Bound to Lead: The Changing Nature of American Power. New York, Basic Books, 1990.

Obervatory of Economic Complexity: What does Libya export. Online: https://oec.world/ en/visualize/line/hs92/export/lby/chn.fra.deu.ita.tun.tur.are.usa/all/2010.2019

Obervatory of Economic Complexity: What does Libya import. Online: https://oec.world/ en/visualize/line/hs92/import/lby/chn.fra.deu.ita.tun.tur.are.usa/all/2010.2019/

OECD: "SME and entrepreneurship issues and policies in Italy: Assessment and recommendations", in Italy: Key Issues and Policies. Párizs, OECD Publishing, 2014. Online: https://doi.org/10.1787/9789264213951-en

Pollinsí, Brian: Does Trade Still Follow the Flag? American Political Science Review, 83. (1989), 2. 465-480. Online: https://doi.org/10.2307/1962400

QualEnergia: Rapporti Libia-Italia, il peso di gas e petrolio. QualEnergia, 2016. március 8. Online: www.qualenergia.it/articoli/20160308-rapporti-libia-italia-il-peso-di-gas-e-petrolio/

Ronzitti, Nicolo: The Treaty on Friendship, Partnership and Cooperation between Italy and Libya: New Prospects for Cooperation in the Mediterranean. Bulletin of Italian Politics, 1. (2009). 125-133.

Sartori, Nicolo: Il Mediterraneo e la sicurezza energetica. In Alessandro Marrone - Michele Nones (szerk.): La sicurezza nel Mediterraneo e l'Italia. Róma, Quaderni IAI, Edizioni Nuova Cultura, 2015.

Sisitema di informazione per la sicurezza della Repubblica: Relazione annuale. 2019. Online: www.sicurezzanazionale.gov.it/sisr.nsf/wp-content/uploads/2020/03/ RELAZIONE-ANNUALE-2019-4.pdf

SRM Maritime Economy: Italian Maritime Economy: China, Energy corridors, ports and new routes: geomaps of a changing Mediterranean (2018. június 5.) Online: www. sr-m.it/wp-content/uploads/2018/06/summary-maritime-report-2018.pdf

SRM: MED \& Italian Energy Report, Energy sources, flows and strategies of Italy between Europe an the Mediterranean, 2019. Online: www.sr-m.it/wp-content/ uploads/2019/04/abstract_ENEMED_19_ENG.pdf

Statista: Volumes of natural gas imported from Libya to Italy from 2010 to 2018. Online: www.statista.com/statistics/807120/volumes-of-natural-gas-imported-fromlibya-to-italy/ 
Torresi, Tiziana: An Emerging Regulatory Framework for Migration. The Libya-Italy Agreement and the Right of Exit. Griffith Law Review, 22. (2013), 3. 648-665. Online: https://doi.org/10.1080/10383441.2013.10877016

TRANSMED: Gas Transportation System. Online: www.transmed-spa.it/sistema_di_ trasporto.php?lingua $=2$

TrendEconomy: Annual International Trade Statistics by Country-Libya. 2020. Online: https://trendeconomy.com/data/h2?commodity=TOTAL\&reporter=Libya\&trade_ flow $=$ Export, Import\&partner=Italy\&indicator $=N W, T Q, T V \&$ time_period=1999, $2000,2001,2002,2003,2004,2005,2006,2007,2008,2009,2010$

TrendEconomy: Annual International Trade Statistics by Country - Italy, 2020. Online: https://trendeconomy.com/data/h2/Italy?time_period=2019,2018,2017,2016, 2015,2014,2013,2012,2011,2010,2009,2008

TrendEconomy: Annual International Trade Statistics by Country - Italy - Libya, 2020. Online: https://trendeconomy.com/data/h2?commodity=TOTAL\&reporter=Italy\&trade_flow=Export,Import\&partner $=$ Libya\&indicator $=N W, T Q, T V \&$ time_period=2008,2009,2010,2011,2012,2013,2014,2015,2016,2017,2018,2019

U.S. Energy Information Administration: Country Analyses Brief: Libya, 2014. Online: www.ieee.es/Galerias/fichero/OtrasPublicaciones/Internacional/2014/EIA_ CountryAnalysisBrief_Libya_25nov2014.pdf

Unione Petrolifera: Pubblicazioni. Online: www.unionepetrolifera.it/pubblicazioni/

Van Genugten, Sofia: Libya in western foreign policies, 1911 to 2011. London, Palgrave MacMillan, 2016. Online: https://doi.org/10.1057/978-1-137-48950-0

Varvelli, Arturo: Le strategie di politica energetica dell'Italia. Criticità interne e opportunità internazionali. Quaderni di Relazioni Internazionali, 22. (2010b). 98-114.

Varvelli, Arturo: Relazioni economiche italo-libiche. Osservatorio di Politica Internazionale, Nota di analisi n. 5. 2008. december 17. Online: www.ispionline.it/sites/default/ files/pubblicazioni/Relazioni\%20italo-libiche.pdf

Varvelli, Arturo: Italy and Libya: Renewing a Special Relationship. The International Spectator, 45. (2010a), 3. 117-130. Online: https://doi.org/10.1080/03932729.2 010.504627

Vecsey Mariann: A Sárkány Afrikában. In Hamar Imre - Besenyő János (szerk.): Kína a globális kihívások tükrében. China In the Light of Global Challenges. Budapest, ELTE Konfuciusz Intézet, 2018. 207-219.

WorldBank: Libya. Online: https://pubdocs.worldbank.org/en/314751603047345007/ pdf/10-mpo-am20-libya-lby-kcm.pdf

WorldBank: The World Bank in Libya - Overview. Online: www.worldbank.org/en/ country/libya/overview

Zallio, Franco: Le deboli onde della crisi. Politica Internazionale, 34. (2009), 1/3. 145-155.

Zotti, Antonio - Enrico Fassi: Immigration and Foreign Policy. Italy's domestic-international linkage in the management of mass human movement. Italian Political Science, 15. (2020), 1. 96-113. 